\title{
ALTERNATIVA ZA NJEMAČKU: PROGRAM, VODSTVO I BIRAČI
}

\author{
Višeslav Raos \\ Fakultet političkih znanosti \\ Sveučilišta u Zagrebu \\ E-mail: viseslav.raos@fpzg.hr
}

\author{
DOI: 10.20901/an.14.02 \\ Izvorni znanstveni rad \\ Prihvaćeno: prosinac 2017.
}

\begin{abstract}
Sažetak Autor razmatra politički profil Alternative za Njemačku kako bi pridonio razumijevanju njezine pojave u političkom životu Njemačke. Analizom izbornih programa provjerava njezin položaj na osi lijevo-desno te stavove o europskim integracijama, nacionalizmu i multikulturalizmu, te o ekonomskoj politici i demokraciji. Multivarijantnom regresijskom analizom ispituje prediktivnu snagu konfesionalnih, dobnih, obrazovnih, migracijskih i ekonomskih obilježja izbornih okruga u objašnjenju varijacije u postotku glasova. Istraživanjem biografskih obilježja članova vodstva stranke testira se pretpostavljena zajednička demografska i ideološka pozadina stranačke elite. Pokazalo se da Alternativa za Njemačku odudara od stavova drugih stranaka u gledanjima na Europsku uniju, nacionalizam, multikulturalizam i ekonomsku politiku, ali ne odskače značajno na osi lijevo-desno, kao ni prema stavovima o demokraciji. Za predikciju glasovanja za tu stranku najvažnijima su se pokazala regionalna (rascjep istok-zapad), dobna i ekonomska obilježja izbornih okruga. Biografska analiza stranačke elita otkriva visok postotak bivših članova njemačkih demokršćanskih stranaka, te prevlast starijih visokoobrazovanih muškaraca u njoj.
\end{abstract}

Ključne riječi Alternativa za Njemačku, nova stranka, njemački stranački sustav, društveni rascjepi, euroskeptičnost

\section{Uvod}

Njemački stranački sustav desetljećima je slovio kao jedan od najstabilnijih u Europi. Uvelike je za to zaslužan personalizirani razmjerni izborni sustav, jedna vrsta kombiniranog sustava, koji nije uspio toliko personalizirati izbore koliko je uspio racionalizirati izborne ponude i sustav učiniti relativno propusnim za nove stranke, zadržavši istodobno visoku razinu razmjernosti i nisku razinu fragmentacije parlamenta (Kasapović 2014: 123-124). Koncentra- cijskim tendencijama, koje su rezultirale stabilizacijom stranačkoga i političkog sustava, uvelike je pomoglo i svojevrsno srastanje etabliranih stranaka s državom kao posljedicom ustavno zajamčene primarne uloge političkih stranaka u oblikovanju političke volje građana, ali i proračunskog financiranja stranaka kao glavnog izvora njihova materijalnog uzdržavanja (Beyme 2017: 166-182). Stabilnome dvoipolstranačkom sustavu pridonijeli su i visoka izborna participacija, masovno sindikalno članstvo, institucionalna stabilnost i izvanjski 
čimbenici, ponajprije prisutnost savezničkih snaga koje su spriječile jačanje protusustavskih stranaka na rubovima političke pozornice. No usponom Zelenih osamdesetih godina i preobrazbom Jedinstvene radničke stranke Njemačke (SED), istočnonjemačke inačice komunističkih partija, najprije u Stranku demokratskog socijalizma (PDS), a potom u Stranku ljevice (LP), njemački se stranački sustav transformirao u višestranački sustav umjerenog pluralizma, koji je Beyme (2017: 205) nazvao "fluidnime petostranačkim sustavom".

Posljednjih godina Njemačka svjedoči porastu volatilnosti i izborne apstinencije, što neke istraživače navodi na zaključak da predstoji ili da je već počela nova preobrazba stranačkog sustava (Schoen i Weßels 2016: 5). Premda su izbori 2013. rezultirali ponovnom dominacijom dviju najvećih stranaka, demokršćana i socijaldemokrata, te, prema Niedermayeru (2015a: 1), obnovom nekadašnjega stabilnog dvoipolstranačkog sustava, uspon Alternative za Njemačku (u nastavku: Alternativa) i urušavanje Socijaldemokratske stranke (SPD) potvrdili su da je njemački stranački sustav ušao u fazu destabilizacije. Ona se očituje u nastavku raslojavanja birača iz istočne i zapadne Njemačke, opadanju mobilizacijskog potencijala dviju velikih stranaka, posebice socijaldemokrata, slabljenju kolektivnih identiteta i njihove organizacijske podloge te porastu prakse cijepanja glasa, to jest glasovanja za kandidata jedne stranke i pokrajinsku listu druge stranke (Manow 2016). Takav je razvoj omogućio pojavu Alternative - stranke o kojoj se mnogo govori, a malo se pouzdano zna.

\section{Stanje istraživanja}

Od osnutka u veljači 2013. ${ }^{1}$ Alternativa pobuđuje živ interes medija i akademske

Pretpovijest stranke malo je dulja. Još u ožujku 2010, kao odgovor na politiku zajednice. Rasprave su se uvelike usredotočile na pitanja o tome je li ta stranka poveznica krajnje desnice s glavnom političkom strujom, koliko je narušena stabilnost stranačkog sustava koji su određivale dvije velike narodne stranke (Volksparteien) te koliko su primjerene usporedbe Alternative s euroskeptičnima, desnim populističkim strankama u drugima zapadnoeuropskim demokracijama, poput Slobodarske stranke Geerta Wildersa u Nizozemskoj i Nacionalne fronte Marine Le Pen u Francuskoj (Berbuir, Lewandowsky i Siri 2015: 154). U mnogim se studijama razmatra je li Alternativa uistinu desna populistička ili jednoproblemska stranka, pri čemu bi prvi problem koji ju je odredio bila kriza eura 2013, a drugi migrantska kriza 2015. Schmitt-Beck (2017: 145146) u analizi birača Alternative između izborâ za Bundestag 2013, Europski parlament i predstavnička tijela triju istočnonjemačkih saveznih pokrajina 2014. pokazuje kako se ukorak s promijenjenom retorikom stranke - pomicanjem naglaska s kritike monetarne politike na pitanja migracija, integracije i kulturnog identiteta - mijenjao i profil birača stranke koji su postajali sve desnijima. Analizirajući rano djelovanje Alternative od osnutka 2013. do europskih izbora u lipnju 2014, (Franzmann 2015: 476) razlikuje populističke komunikativne i diskurzivne taktike privlačenja birača od političkog sadržaja u izbornom programu koji nema jasnih populističkih obilježja. Neki su istraživači stavili stranku u kontekst prosvjednog djelovanja, to jest fenomena prosvjednih stranaka kao

Angele Merkel prema grčkoj dužničkoj krizi i s njome povezanoj krizi eurozone koja je prijetila i njemačkima mirovinskim fondovima i bankarskom sektoru, profesor makroekonomije i prvi vođa stranke Bernd Lucke osnovao je "Plenum ekonomista" kao skupinu za pritisak koja će javnim djelovanjem nuditi alternativan pogled na njemačku i europsku monetarnu i fiskalnu politiku (Niedermayer 2015b: 177). 
"ispušnih ventila" za razne vrste društvenoga i političkog nezadovoljstva, ali bez jasnijih programskih smjernica (Schwarzbözl i Fatke 2016). Drugi pak ističu sintagmu "stranka novog tipa", pokušavajući objasniti kako je stranka koju su osnovali desni liberali, kritičari spašavanja eurozone, mahom profesori makroekonomije, postala zbornim mjestom različitih desnih prosvjednih glasova, zaogrnutih populističkom retorikom, koji tvrde da Alternativa nije "ni lijevo ni desno" (Gebhardt 2013).

Istraživači koji su se ozbiljno usredotočili na nastanak i razvoj stranke ubrzo su primijetili da se ona brzo transformirala iz jednoproblemske stranke, kritičara eurozone, u stranku koja zahvaća desno liberalno, ali i nacionalno konzervativno biračko tijelo desnije od Kršćansko-demokratske (CDU) i Kršćansko-socijalne unije (CSU) te se pozicionira na tragu novog rascjepa nacionalno-internacionalno, to jest zahtijeva vraćanje "nacionalnoga u političko" (Häusler 2016: 239). Populistička retorika i komunikacijske strategije pritom su ljepilo koje spaja disparatne političke struje u catch-all-stranku desniju od kršćanskih demokrata i liberala. Alternativa stoga nije desna populistička nego catch-all-stranka desnija od desnog centra.

\section{Metodologija i podaci}

Da bih osvijetlio profil Alternative, upotrijebit ću nekoliko analitičkih razina. Prva razina tiče se dimenzije političke ponude, odnosno izbornih programa koje je stranka objelodanila uoči parlamentarnih izbora 2013. i 2017. Ona se temelji na kvantitativnoj analizi sadržaja koja je razvijena u okviru međunarodne istraživačke mreže Comparative Manifestos Project (CMP). Podaci o njemačkim strankama pribavljeni su $\mathrm{s}$ javno dostupnog repozitorija Manifesto Projecta, nastavka CMP-a, koji koordi- nira skupina istraživača kojoj je sjedište u berlinskom Wissenschaftszentrum für Sozialforschung (WZB). Iz te baze (Volkens i dr. 2017b) izdvojeni su podaci o svim strankama koje su na parlamentarnim izborima od 1990. do 2017. osvajale mandate u Bundestagu, uz podatke o Alternativi koja je 2013. ostala ispod izbornog praga, da bi na izborima 2017. zadovoljila obje prohibitivne klauzule u izbornom sustavu - osvojila je pet posto glasova na saveznoj razini i najmanje tri izravna mandata u izbornim okruzima. ${ }^{2}$

Analizira se deset dimenzija izbornih programa stranaka koji su kodirani prema šifrarniku Manifesto Projecta: položaj na osi lijevo-desno, ${ }^{3}$ stavovi o europskim integracijama, nacionalnom načinu života i multikulturalizmu, tri dimenzije ekonomske politike te tri dimenzije koje mjere odnos prema osobnima i građanskim pravima, demokraciji i ustavnom poretku. Svrstavanje izbornih programa političkih stranaka i stavova birača na osi lijevo-desno od sredine sedamdesetih godina i pojave utjecajne studije Ingleharta i Klingemanna (2010) postalo je standardan alat u analizi stranaka i stranačkog natjecanja. Uzevši u obzir da studije o Alternativi (Berbuir, Lewandowsky i Siri 2015: 154-155; Grimm 2015: 272-273; Decker 2016: 10-13; Grabow 2016: 177-178; Häusler, Roeser i Scholten 2016: 16-23) stavljaju naglasak na dvojbu o tome treba li tu stranku svrstati u populističku desnicu, koja značajno odstupa od javnih politika kakve nude glavne njemačke stranke, prvo je istraživačko pitanje: može li se otkriti značajan raskorak između pozicija Alternative i drugih parlamentarnih stranaka od ujedinjenja Njemačke do 2017. na osi lijevo-desno?

\footnotetext{
Više o funkcioniranju njemačkoga izbornog sustava u: Kasapović 2014: 99-104.

3 Kao mjera položaja na osi lijevo-desno koristi se RILE-indeks (varijabla rile), oblikovan u okviru Manifesto Projecta (Volkens 2017a; prema: Laver i Budge 1992).
} 
Sljedeće tri dimenzije izabrane su zato što su kvalitativna istraživanja pokazala da su Europska unija odnosno europske integracije, nacionalni identitet i imigracija ključni sadržaji izbornih programa Alternative (Häusler, Roeser i Scholten 2016: 24-31). Da bi se ispitao odnos stranaka prema Europskoj uniji, odabrane su varijable per108 (pozitivne izjave o Europskoj uniji i njezinim institucijama u programima stranaka) i per110 (negativne izjave) iz šifrarnika Manifesto Projecta (Volkens i dr. 2017a: 11). Izračunom razlike između rezultata programa stranaka prema per108 i per110 dobivene su vrijednosti kod kojih više brojke impliciraju pozitivan stav prema Europskoj uniji, a niže euroskeptičniji stav. Drugo istraživačko pitanje glasi: je li Alternativa značajno euroskeptičnija od ostalih stranaka koje su bile zastupljene u Bundestagu od 1990. do 2017? Premda naoko razumljivo samo po sebi zbog medijskog "brendiranja" Alternative kao prvaka euroskeptičnosti u Njemačkoj, to se pitanje zapravo nastavlja na rasprave koje su utvrdile porast euroskeptičnosti u njemačkom društvu, ali i prazninu na prostoru stranačkog natjecanja koju bi mogla popuniti neka euroskeptična opcija (Rohrschneider i Whitefield 2017). Kao mjerilo nacionalizma - naglašavanja nacionalnog identiteta, ponosa i očuvanja povijesti i tradicije - odabrane su varijable per601 (National Way of Life: Positive) i per602 (National Way of Life: Negative) (Volkens i dr. 2017: 18). Izračunom razlike između rezultata programa stranaka prema per601 i per602 dobivene su vrijednosti kod kojih više brojke impliciraju veću prisutnost nacionalističkih pozicija u stranačkom programu, a niže brojke manju prevalenciju takvih stavova. Cilj je dobiti odgovor na pitanje je li Alternativa zastupala nacionalističke vrijednosti značajno više od ostalih parlamentarnih stranaka od 1990. do 2017. Odnos prema imigran- tima i stavovi o načinu njihova prilagođavanja domicilnom društvu i kulturi ispituju se pomoću varijabli per607 (Multiculturalism: Positive) i per608 (Multiculturalism: Negative) (Volkens i dr. 2017: 20). Izračunom razlike između rezultata programa stranaka prema per607 i per608 dobivene su vrijednosti kod kojih više brojke impliciraju veću prisutnost afirmativnih iskaza o multikulturalizmu u stranačkom programu, a niže brojke veću sklonost odbacivanju tog koncepta i zastupanja snažnije integracije useljenika koja vodi ka asimilaciji. Prema tome, četvrto istraživačko pitanje glasi: odbacuje li Alternativa multikulturalizam nasuprot drugačijim stavovima ostalih parlamentarnih stranaka u Njemačkoj?

Nadalje, cilj je odgovoriti na pitanje zastupa li Alternativa ekonomski značajno desniju politiku od ostalih parlamentarnih stranaka u Njemačkoj, budući da je inicijalno nastala kao stranka kritičara monetarne i fiskalne politike Angele Merkel u kontekstu dužničke krize i krize zajedničke europske valute te su njezini osnivači bili profesori makroekonomije koji zagovaraju niže poreze, uravnotežen proračun i manje upletanja savezne vlade (i Europske komisije) u njemačko gospodarstvo. Da bi se ispitali stavovi iskazani u stranačkim programima koji mogu implicirati ekonomsku ljevicu odnosno ekonomsku desnicu, odabrane su tri kompozitne varijable iz šifrarnika - planeco, markeco i welfare - koje se uobičajeno koriste kako bi se odredio ideološki profil stranke u ekonomskim pitanjima. ${ }^{4}$ Veće vrijednosti prema indeksu planeco impliciraju snažniju suglasnost stranke s potrebom državnog reguliranja tržišnih i radnih odnosa te ekonomskog planiranja, veće vrijednosti prema indeksu markeco svjedoče o snažnijem zauzimanju stranke za

4 Prve dvije varijable također su sadržane u varijabli rile, dok treća nije. 
nesputanu tržišnu utakmicu i smanjivanje uloge države u ekonomiji, a veće vrijednosti prema indeksu welfare pokazuju da se stranka zauzima za ekspanziju države blagostanja i da ostvarenje socijalno-ekonomske jednakosti smatra važnom zadaćom države.

Naposljetku, uzevši u obzir da su mediji i druge političke stranke Alternativu često prikazivali kao stranku koja ne prihvaća liberalno-demokratski ustavni poredak te ugrožava ljudska i građanska prava u Njemačkoj, s jedne strane, a čelnici Alternative isticali su kako žele demokraciju vratiti građanima te su kritizirali stranačke elite, ponajprije dviju velikih stranaka, zato što vode državu na netransparentan način bez dostatne odgovornosti prema biračima, s druge strane, posljednje istraživačko pitanje na ovoj razini analize glasi: postoji li značajan raskorak u stavovima o osobnim slobodama i gradanskim pravima, demokraciji $i$ ustavnom poretku izmedu Alternative $i$ drugih parlamentarnih stranaka u Njemačkoj? Pri tome su iz šifrarnika uzete varijable per201 (Freedom and Human Rights), per202 (Democracy), te izračun razlike među rezultatima stranaka prema varijablama per203 (Constitutionalism: Positive) i per204 (Constitutionalism: Negative). ${ }^{5}$ Veće vrijednosti impliciraju naglašavanje važnosti osobnih sloboda i građanskih prava, demokracije i političke participacije građana te zauzimanje za očuvanje postojećega ustavnopravnog okvira.

Druga razina osvjetljavanja političkog profila Alternative obuhvaća proučavanje političke potražnje, to jest strukture biračkog tijela u kojemu je stranka osvojila značajan broj glasova. Preciznije, taj se dio analize temelji na strukturnima demografskim podacima koji su mogli

5 U varijabli rile sadržane su varijable per201 i per202 te per203, ali nije uključena varijabla per204. biti prediktori rezultata Alternative na parlamentarnim izborima 2017. Izvori za tu analizu, objedinjeni na stranicama njemačkoga izbornog povjerenstva (Bundeswahlleiter), jesu podaci prikupljeni u sklopu popisa stanovništva 2011. te podaci Regionalne baze podataka Njemačke (Regionaldatenbank Deutschland) i Savezne agencije za rad iz 2015. (BWL 2017a). Izborni rezultati Alternative, koji se koriste u ovoj analizi, odnose se na postotke drugih glasova na razini izbornih okruga (BWL 2017b).

$\mathrm{U}$ analizu su uključene varijable koje se odnose na konfesionalni rascjep (ostali $i$ konfesionalno neopredijeljeni), dobni rascjep (udio stanovništva iznad 75 godina), jedan migracijski (udio nedržavljana) i jedan socijalno-ekonomski prediktor (udio nezaposlenih) te jedna obrazovna varijabla (udio gradana koji nisu završili nižu srednju školu). ${ }^{6}$ Istraživanja društvenih rascjepa pokazala su da konfesionalni i klasni rascjepi još mogu biti dobar prediktor izbornog uspjeha njemačkih stranaka (Elff $i$ Roßteutscher 2011: 124), unatoč brojnima društvenim promjenama koje su uzrokovane prelaskom iz industrijskoga u postindustrijsko društvo i opadanjem članova crkava, sindikata i udruga. Stoga su i u ovo istraživanje uvedene varijable koje prate utjecaj konfesionalne strukture izbornog okruga na izborni ishod. Od tri moguće kategorije u korištenoj bazi podataka (katolici, protestanti, ostali i konfesionalno neopredijeljeni), odabrana je posljednja kategorija kako bi se ispitalo može li se visoka prisutnost te skupine stanovnika u izbornom okrugu koristiti za predikciju glasa za Alternativu, analogno prethodnim istraživanjima koja pokazuju kako,

6 Niža srednja škola (Hauptschule) daje temeljno i osposobljava za strukovno obrazovanje, dok se pod srednjim školama, ekvivalentnima gimnaziji, smatraju škole koje imaju završni ispit koji omogućuje pristup visokom školstvu. 
primjerice, većinski katolički izborni okruzi povećavaju vjerojatnost glasovanja za CDU-CSU. Dostupni podaci nisu omogućavali odabir varijabla koje bi izravno mjerile klasna obilježja izbornog okruga, pa je kao zamjenska socijalno-ekonomska varijabla uveden udio nezaposlenih. On je zanimljiv i zato što neki autori ističu kako Alternativa mobilizira "modernizacijske gubitnike" (Lengfeld 2017), od kojih su mnogi ostali bez radnog mjesta. Ipak, novija istraživanja društvenih rascjepa i njihove uloge u objašnjenju izbornih ishoda u Njemačkoj pokazuju relativnu stabilnost konfesionalnoga, ali slabljenje klasnog rascjepa: primjerice, radništvo nije više predisponirano glasovati za socijaldemokrate, dok je stupanj religioznosti još uvijek jasan prediktor preferiranja demokršćana (Elff i Roßteutscher 2016: 59). Umjesto klasičnih socijalno-ekonomskih varijabla, uvedena je jedna obrazovna varijabla, pretpostavljajući da će veći udio slabije obrazovanih u izbornom okrugu implicirati veći broj modernizacijskih gubitnika, koji se na istoku zemlje mogu tumačiti i kao tranzicijski gubitnici. Migracijski prediktor uveden je zbog snažne povezanosti mobilizacijskog potencijala Alternative i teme integracije useljenika i novopridošlih stanovnika tijekom migrantske krize 2015. (Grabow 2016). Također, uvedena je dobna varijabla koja se u prijašnjima longitudinalnim ispitivanjima prediktora izbornih ishoda u Njemačkoj pokazala važnom (Debus 2010). Kao dobna varijabla izabrana je najstarija kohorta stanovnika (udio stanovnika koji imaju 75 i više godina), uz pretpostavku da bi visok udio starog stanovništva u izbornom okrugu mogao biti dobar prediktor glasovanja za stranku (Alternativu) koja mobilizira bojazni od ekonomskih i kulturnih promjena, a koje bi mogle imati snažniji odjek u sredinama s više starijih birača.
$\mathrm{Na}$ temelju tih prediktora pokušat ću pomoću multivarijantne regresijske analize ispitati u kojoj se mjeri može govoriti da neki društveni rascjepi određuju izborni uspjeh Alternative. Drugim riječima, cilj je ispitati postoje li prepoznatljive socijalno-demografske značajke izbornih okruga u kojima ta stranka osvaja visoke postotke drugih glasova, dakle glasova danih stranačkim listama nasuprot prvim glasovima koji se daju pojedinačnim kandidatima u većinskom dijelu izbora.

Osim strukturnih prediktora koji pomažu da se objasni utjecaj socijalno-demografske strukture izbornog okruga na izborni uspjeh Alternative, uvedena je i dihotomna (dummy) varijabla koja uzima u obzir teritorijalni rascjep između istoka i zapada zemlje. Prema toj varijabli, vrijednost 1 dobili su svi izborni okruzi koji se nalaze na području nekadašnje Njemačke Demokratske Republike (DDR), a vrijednost 0 svi okruzi koji su se i prije ujedinjenja 1990. nalazili u Saveznoj Republici Njemačkoj (BRD).

Treća razina analize temelji se na analizi političkih biografija članova vodstva stranke. Uzorak čine svi članovi Saveznog odbora kao najvišega stranačkog gremija u zemlji i predsjednici pokrajinskih odbora stranke, to jest čelnici podružnica stranke u saveznim pokrajinama. Alternativa, poput Zelenih i Ljevice, prakticira dvojno vodstvo stranke, počesto uz rodni paritet, makar na saveznoj razini. No ne prakticiraju svi pokrajinski ogranci dvojno vodstvo pa, primjerice, postoji jedna predsjednica pokrajinskog odbora u Schleswig-Holsteinu, ali dva predsjednika pokrajinskog odbora u Mecklenburgu-Zapadnom Pomorju. Analiza stranačke elite nadovezuje se na postojeća istraživanja članstva stranke i njezinih kandidata za parlamentarne, pokrajinske ili europske izbore. Bebnowski (2015: 19-31) u 
iscrpnoj studiji tema, struja i krila te vrlo heterogene stranke ocrtava grupacije sklone ekonomskom liberalizmu, kršćanske konzervativce, posrednike između mainstreama i rubnih političkih skupina te desne populiste. ${ }^{7}$ Anketa među kandidatima za izbore 2013. pokazala je da je Alternativu teško svrstati u desne populističke stranke, budući da su njezini kandidati mahom bili ekonomski liberalniji od kandidata stranaka Unije i nisu iskazivali izražene autoritarne stavove, osim kandidata s istoka zemlje koji su bili autoritarniji od stranačkih kolega iz zapadnih ogranaka (Jankowski, Schneider i Tepe 2017). U tom se radu, među ostalim, kao prediktori rezultata ispitanih kandidata na osi liberalizam-socijalizam i slobodarsko-autoritarno koriste dob, spol, obrazovanje i matični dio zemlje (Jankowski, Schneider i Tepe 2017: 712). Stoga je biografska baza podataka o stranačkom vodstvu izrađena prema sljedećim kriterijima: matična savezna pokrajina, to jest pokrajina u kojoj je pojedinac bio učlanjen u stranački ogranak, mjesto i savezna pokrajina u kojoj je pojedinac rođen (uz dodatno razlikovanje rođenih na istoku i zapadu zemlje), spol, dob, obrazovanje, konfesionalna pripadnost, prethodni posao (prije ulaska u politiku) te prethodno stranačko članstvo. Prethodno stranačko članstvo zanimljiva je varijabla zato što su dosadašnja istraživanja utvrdila kako postoje stanovita preklapanja biračkih tijela Liberalne stranke (FDP), Unije i Alternative (Berbuir, Lewandowsky i Siri

Potonje bi bilo ispravnije nazivati njemačkim nacionalistima među kojima ima $\mathrm{i}$ onih koji su skloni povijesnom revizionizmu, ponajprije na području kulture sjećanja. Riječ je o grupaciji oko vođe tirinškog ogranka stranke Björna Höckea koji, nasuprot uvriježenom narativu suočavanja s nacionalsocijalizmom i holokaustom, želi promicati nacionalni ponos na "tisućljetnu njemačku povijest" i "hrabre vojnike" (Focus.de 2017).
2015). Ispitivanje prethodnog članstva vodstva Alternative u drugim strankama zanimljivo je i zato što je Bebnowski (2015: 24-31) utvrdio integrativne socijalne mreže kojima su pojedinci preko Alternative povezali društveni mainstream s rubnima političkim grupacijama na desnici. Postavlja se stoga pitanje nalaze li se u vodstvu Alternative i bivši članovi stranaka poput Republikanaca (Die Republikaner) ili Nacionalnodemokratske stranke Njemačke (Nationaldemokratische Partei Deutschlands, NPD).

Naposljetku su dodane još tri specifične varijable: vojna karijera, članstvo u Burschenschaften i obiteljska poveznica s Heimatvetriebene. Prethodna vojna karijera nameće se kao zanimljiv prediktor kasnijega političkog djelovanja zato što ističe red i mir, nacionalnu sigurnost, stabilnost i oštro kažnjavanje prekršitelja zakona. Članstvo u Burschenschaften, jednoj grani njemačkih studentskih bratstava koja se obično povezuju sa snažnima nacionalističkim tendencijama, moglo bi biti dobar prediktor političke opcije koja naglašava nacionalni identitet i borbu protiv prekomjerne imigracije. Okrenutost "boljoj" i "slavnijoj" prošlosti te naglašavanje etničke komponente njemačkoga nacionalnog identiteta moguće je pak povezati s obiteljskim iskustvom $\mathrm{Hei}$ matvetriebene, etničkih Nijemaca koji su prisilno napustili područja Srednje i Istočne Europe, bilo da je riječ o teritorijima koji su prije Drugoga svjetskoga rata pripadali Njemačkoj bilo da su posrijedi bile manjinske zajednice u drugim državama. Za uvid u biografijska obilježja vodstva stranke korišteni su javno dostupni podaci na mrežnim stranicama pojedinih ogranaka Alternative i novinske analize kandidata za parlamentarne izbore od kojih su mnogi visoki stranački dužnosnici (Biermann 2017). 
Grafikon 1. Njemačke parlamentarne stranke na osi lijevo-desno, 1990-2017.

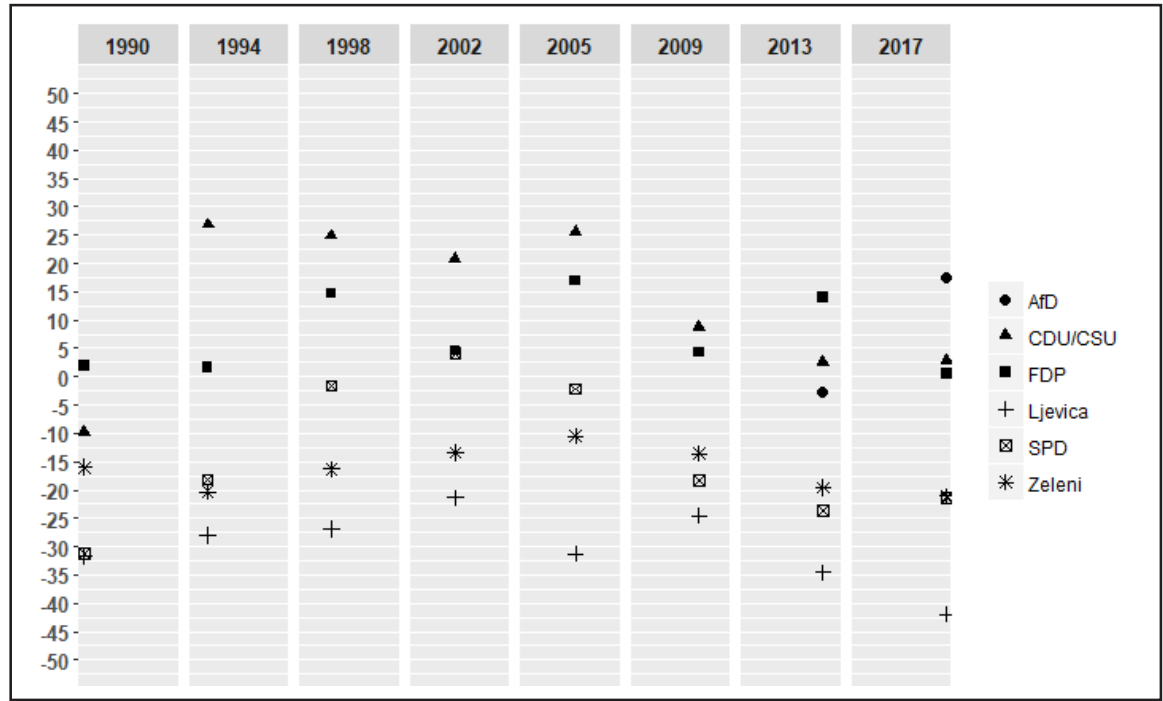

Izvor: izradio autor prema Volkens i dr. 2017b.

Napomena: vrijednosti manje od nule predstavljaju stavove na lijevome, a vrijednosti veće od nule stavove na desnom polu osi.

Grafikon 2. Njemačke parlamentarne stranke i stavovi o Europskoj uniji, 1990-2017.

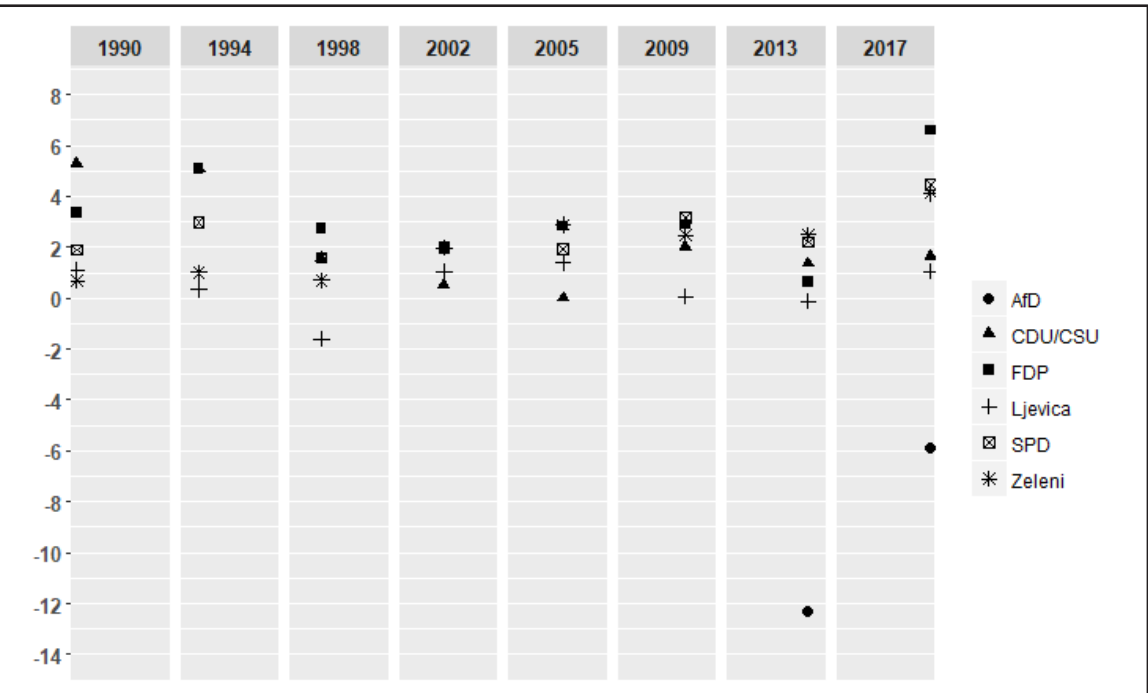

Izvor: izradio autor prema Volkens i dr. 2017b.

Napomena: veće vrijednosti predstavljaju više pozitivnih izjava o Europskoj uniji u stranačkom programu.

\section{Analiza i rasprava}

Analiza kodiranih izbornih programa svih političkih stranaka koje su od 1990. do 2017. osvajale mandate u Bundestagu proizvela je deset komparativnih grafikona koji omogućuju uvid u vremenske promjene stavova njemačkih stra- 
Grafikon 3. Njemačke parlamentarne stranke i stavovi o nacionalnom načinu života, 1990-2017.

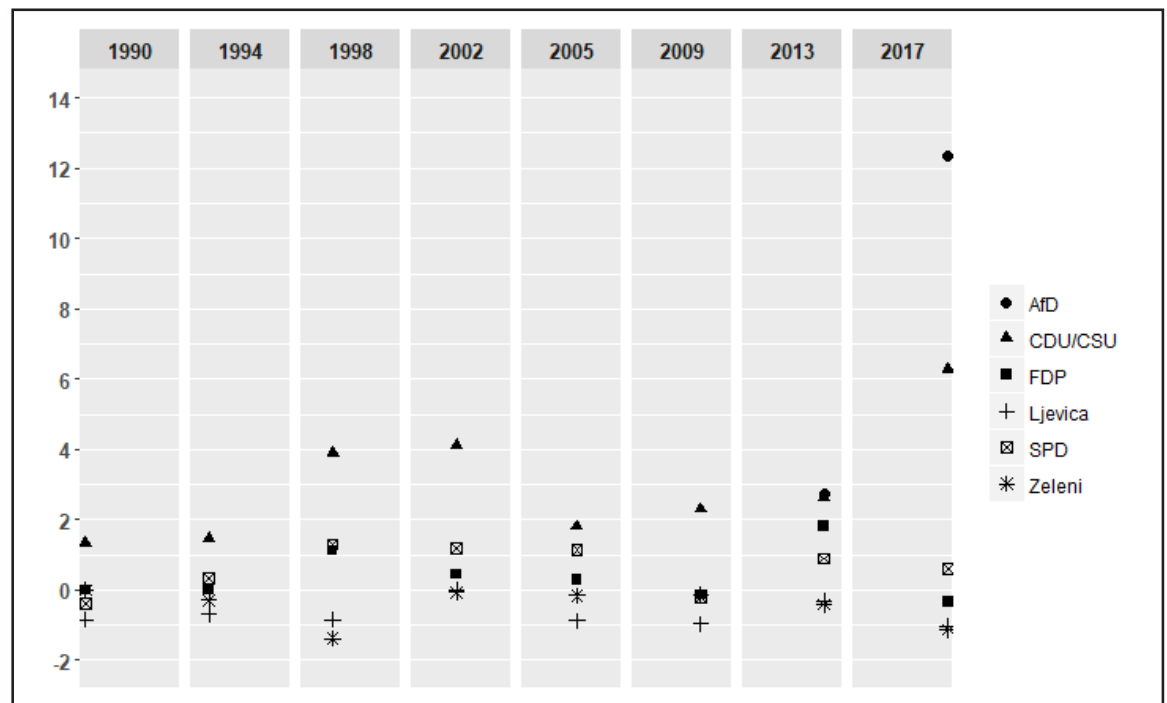

Izvor: izradio autor prema Volkens i dr. 2017b.

Napomena: veće vrijednosti predstavljaju više pozitivnih izjava o nacionalnom načinu života u stranačkom programu..

naka od ujedinjenja do 2017, s jedne, i određivanje pozicije Alternative prema ostalim članicama stranačkoga sustava, s druge strane. ${ }^{8}$ Iz grafikona 1 . može se iščitati nekoliko temeljnih tendencija u ideološkim pomacima u njemačkome stranačkom sustavu. Prvo, CDU-CSU značajno se pomakao ne samo prema centru, nego i prema lijevom centru. Drugo, SPD se pomicao prema centru, pa i desnom centru, sve do 2005. kada se vraća na svoje tradicionalne pozicije. Treće, Alternativa se doista između izbora 2013. i 2017. značajno pomaknula udesno (Franzmann 2016; Schmitt-Beck 2017). No polazišna pozicija ni 2013. ni 2017. na osi lijevo-desno nije se nalazila desnije od nekadašnjih pozicija stranaka Unije. Još 2013. CDU-CSU se nalazio na poziciji blagoga desnog centra, dok je Alternativa bila gotovo čisti centar. Al-

8 U longitudinalnoj komparaciji Stranka demokratskog socijalizma (PDS) i Stranka ljevice odnosno Ljevica (Die Linke, DL) tretiraju se kao jedna stranka, kao što se CDU i CSU navode kao jedna stranka. ternativa, dakle, na osi lijevo-desno ne odudara značajno od vrijednosti drugih aktera stranačkog sustava nakon ujedinjenja Njemačke.

Alternativa je nastala kao stranka prosvjednika protiv politike spašavanja eurozone, što je uključivalo kritiku njemačke vlade i Europske komisije. Tijekom 2015. ta se kritika premjestila na snažno opiranje migrantskoj politici, ali je bila usmjerenija na kancelarku Angelu Merkel nego na predsjednika Europske komisije Jeana-Claudeua Junckera. Ipak, bilo bi očekivano da analiza stavova o Europskoj uniji u izbornim programima pokaže da je Alternativa ispunila prazan prostor za predstavljanje euroskeptičnih građana Njemačke (Grimm 2015; Rohrschneider i Whitefield 2017). Doista, grafikon 2. pokazuje gotovo jednoglasnu potporu njemačkih parlamentarnih stranaka Europskoj uniji, pa u stranačkim programima prevladavaju pozitivni iskazi o njoj i njezinim institucijama. Stanovite iznimke 
Grafikon 4. Njemačke parlamentarne stranke i stavovi o multikulturalizmu, 19902017.

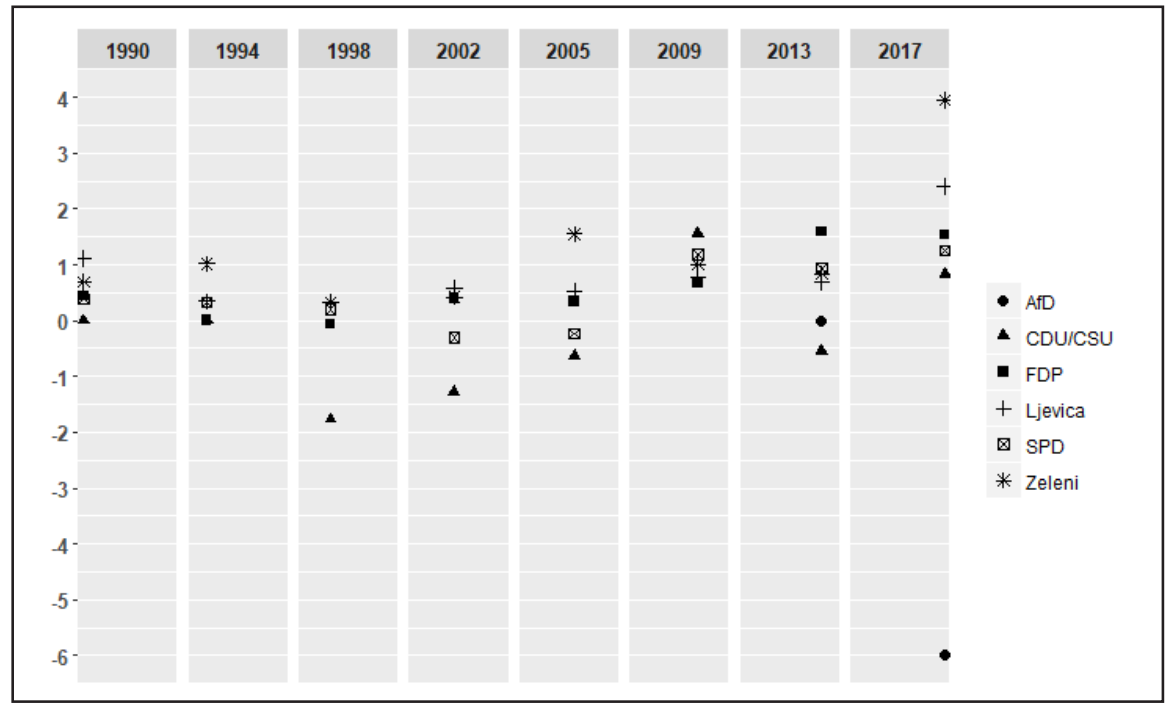

Izvor: izradio autor prema Volkens i dr. 2017b.

Napomena: veće vrijednosti predstavljaju više pozitivnih izjava o multikulturalizmu u stranačkom programu.

čine nešto negativniji stavovi Ljevice 1998. i stranaka Unije 2005. No, kao što je bilo očekivano, Alternativa je 2013. ekstremno odskakala svojim negativnim stavom o Europskoj uniji. Premda je on na izborima 2017. znatno ublažen, ostao je snažan raskorak između negativnog stava Alternative i gotovo posve pozitivnog stava svih ostalih parlamentarnih stranaka.

Navedeno je da se Alternativa smatra i mogućim mjestom susreta njemačkih nacionalista i utočištem onih koji naglašavaju nacionalnu kulturu, povijest $i$ identitet Njemačke. Takva se orijentacija očituje i u rezultatima koji su prikazani u grafikonu 3. Rezultati CDU-a i CSU-a ponešto odudaraju od ostalih stranaka u stranačkom sustavu do prijelaza u 21. stoljeće, a 2013. postali su identični rezultatima Alternative. No 2017. Alternativa odskače na toj dimenziji od svih ostalih stranaka, dok se istodobno CDU-CSU odvajaju od liberala, stranaka lijevog centra i ljevice. To se može objasniti stanovitima retoričkim zaokretom Angele Merkel i cijele Unije u kampanji 2017. kada se očekivalo da će Alternativa osvojiti značajan broj glasova, pa se snažnijim nacionalnim nabojem nastojao privući dio razočaranih birača demokršćana koji bi mogli pretrčati Alternativi.

Analiza stavova njemačkih stranaka o multikulturalizmu, koji su prikazani u grafikonu 4, otkriva sličan obrazac ideoloških pomaka koji je utvrđen i kod prethodnih varijabla. Naime, sve su ostale stranke imale naglašeno pozitivan stav prema multikulturalizmu, pri čemu je CDU-CSU na prijelazu stoljeća imao niže vrijednosti, odnosno veći odmak od koncepta multikulturalizma. No poslije, od jednoga do drugoga izbornog ciklusa, mijenja poziciju da bi se 2013. sve stranke našle na istom mjestu gotovo potpuno prihvaćajući multikulturalizam kao pozitivan koncept. S pojavom Alternative 2013, CDU-CSU opet zaoštrava kritiku tog modela inte- 
Grafikon 5. Njemačke parlamentarne stranke i stavovi o planskoj ekonomiji, 19902017.

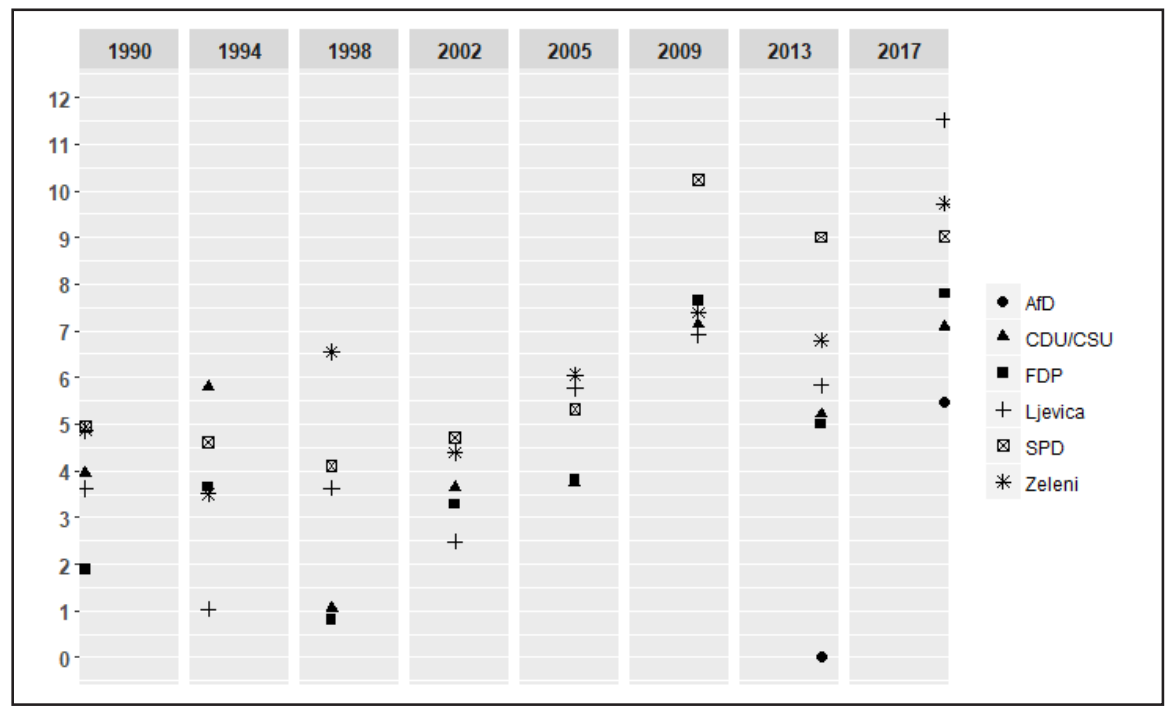

Izvor: izradio autor prema Volkens i dr. 2017b.

Napomena: veće vrijednosti predstavljaju više pozitivnih izjava o planskoj ekonomiji u stranačkom programu.

gracije, ${ }^{9}$ da bi 2017. Alternativa zauzela gotovo isključivo negativan stav, jako udaljen od pozicija ostalih stranaka, među kojima su se stranke Unije ponovno pomaknule prema višim vrijednostima, odnosno većem prihvaćanju multikulturalizma. I u tom je slučaju, dakle, potvrđena teza da u odbacivanju multikulturalizma Alternativa značajno odstupa od ostalih njemačkih stranaka.

Analiza stavova o planskoj ekonomiji, odnosno pozitivnih iskaza o ekonomskom planiranju, kontroli tržišnih mehanizama i državnoj intervenciji u gospodarstvo kao pokazatelja privrženosti ekonomskoj ljevici otkriva kako su se stavovi njemačkih političkih stranaka u promatranom razdoblju o tim temama približili, uz postupno ukupno skretanje ulijevo. Posebno treba istaknuti kako je SPD nakon ekonomskih reformi

9 Taj se zaokret može diskurzivno pratiti od 2010. kada je Merkel izrekla poznatu rečenicu kako je "multikulturalizam propao" (Spiegel.de 2010).
Gerharda Schrödera opet počeo isticati afirmativnije stavove o planskoj ekonomiji, napose na izborima 2009. Nasuprot tome, Alternativa je 2013. postigla vrijednost 0 , odnosno nije imala nijedan pozitivan iskaz o planskoj ekonomiji u izbornom programu. Na sljedećim izborima raskorak u stavovima Alternative i drugih stranaka značajno se smanjio, ali je ta stranka najviše odbijala da se pozitivno odredi o tim temama, odnosno bila je najudaljenija od ekonomske ljevice.

Promotri li se razvoj stavova stranaka o slobodnoj tržišnoj ekonomiji, odnosno iskaza o nesputanome tržišnom natjecanju, uočljivo je kako su gotovo tijekom cijelog razdoblja odskakali liberali (FDP). No 2013. Alternativa je imala više afirmativnih stavova o tržišnoj ekonomiji od liberala, da bi se 2017. ponovno pomaknula $\mathrm{k}$ centru, ali je ostala ekonomski vidno desnije od stranaka Unije koje su u cijelom razdoblju, osim 2005, bile mnogo bliže 
Grafikon 6. Njemačke parlamentarne stranke i stavovi o tržišnoj ekonomiji, 19902017.

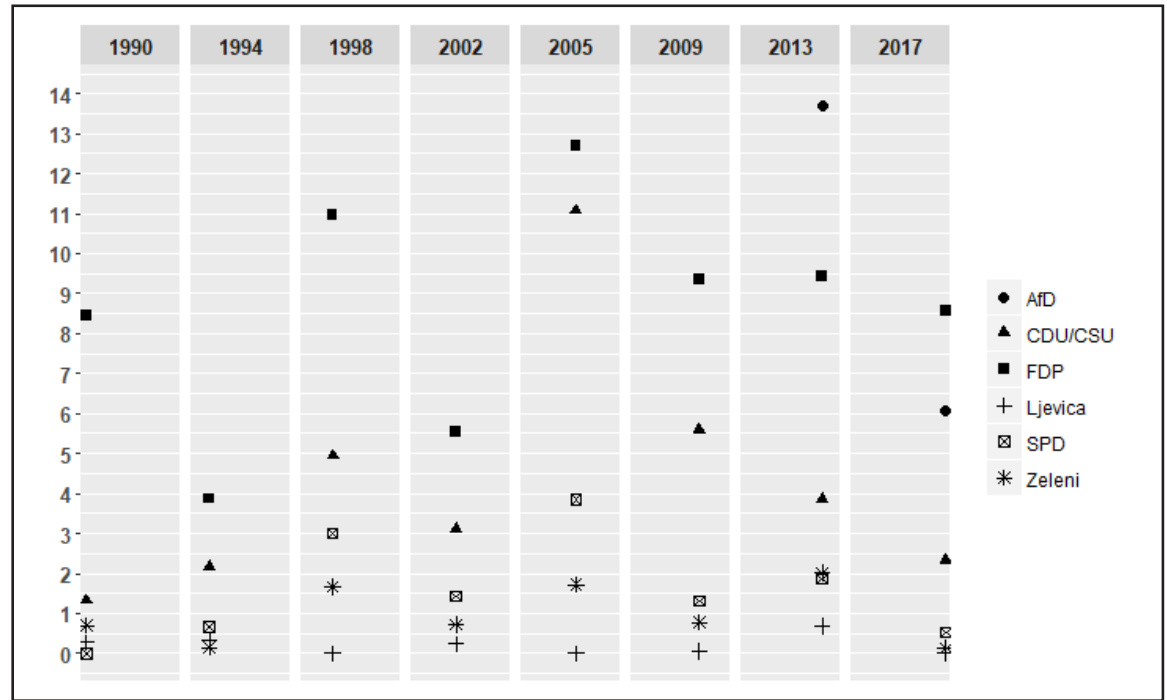

Izvor: izradio autor prema:Volkens i dr. 2017b.

Napomena: veće vrijednosti predstavljaju više pozitivnih izjava o tržišnoj ekonomiji u stranačkom programu.

Grafikon 7. Njemačke parlamentarne stranke i stavovi o državi blagostanja, 19902017.

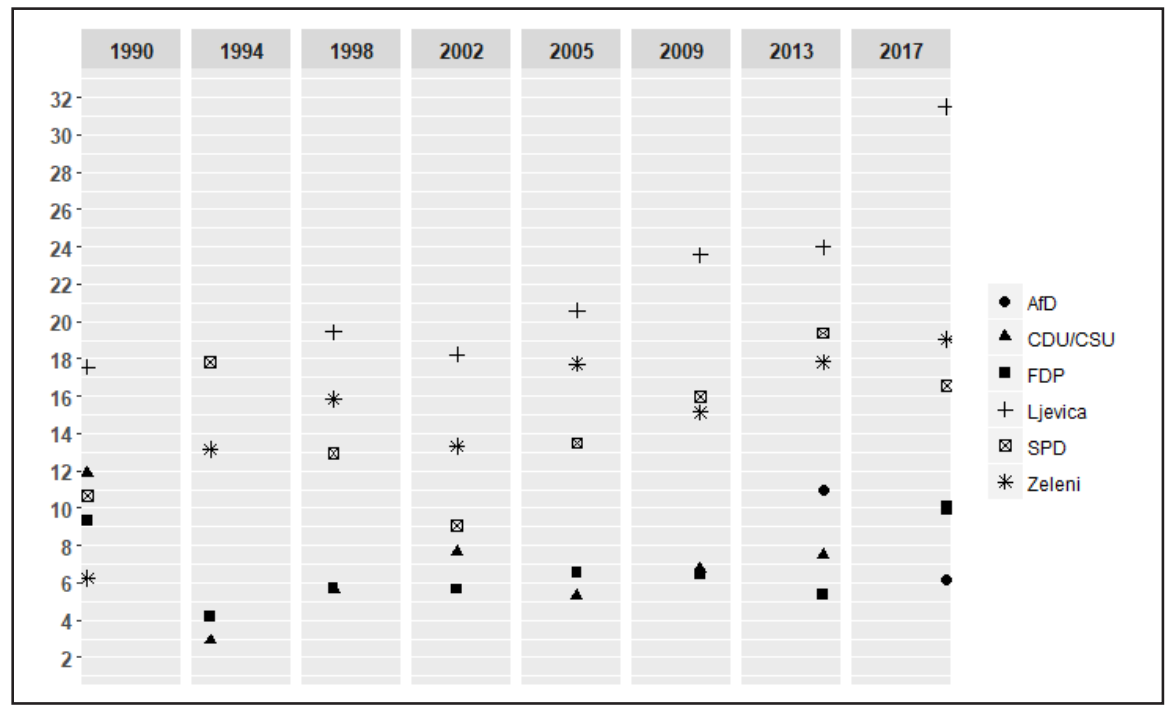

Izvor: izradio autor prema Volkens i dr. 2017b.

Napomena: veće vrijednosti predstavljaju više pozitivnih izjava o državi blagostanja u stranačkom programu.

centru nego liberali. Može se zaključiti kako Alternativa prema toj varijabli možda nije ekonomski najdesnija nje- mačka stranka u promatranom razdoblju, ali se svakako pozicionirala desnije od CDU-a i CSU-a. 
Grafikon 8. Njemačke parlamentarne stranke i stavovi o osobnim slobodama i građanskim pravima, 1990-2017.

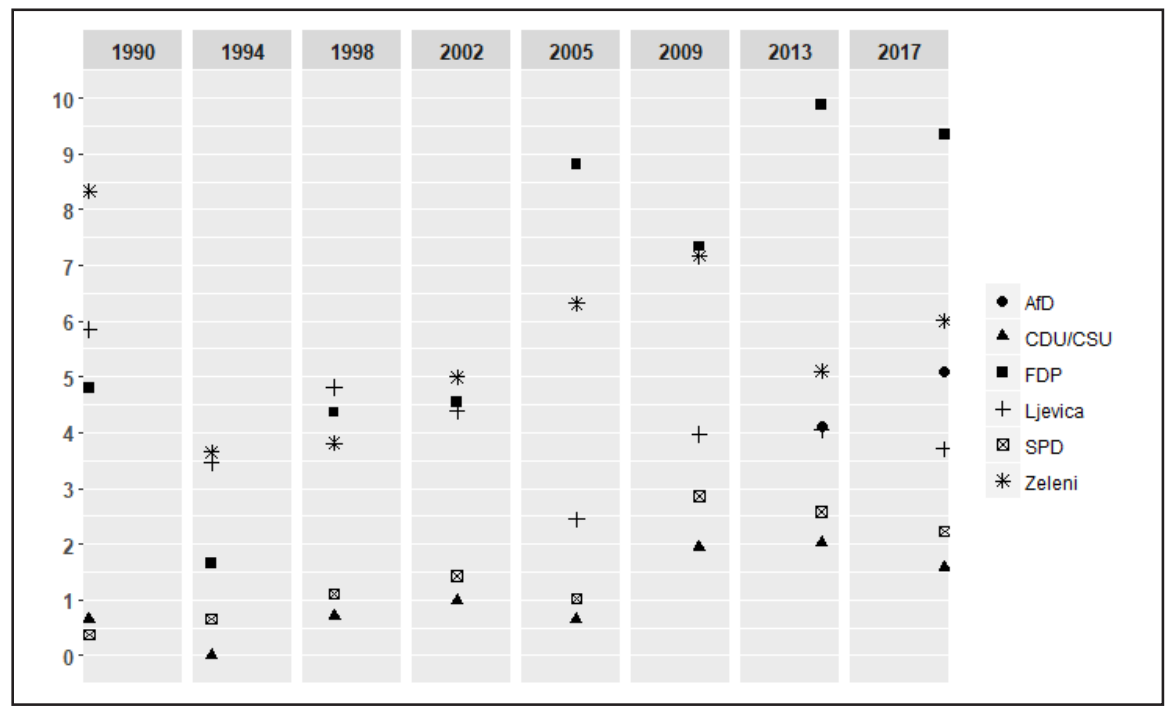

Izvor: izradio autor prema Volkens i dr. 2017b.

Napomena: veće vrijednosti predstavljaju više pozitivnih izjava o osobnim slobodama i građanskim pravima u stranačkom programu.

Prema varijabli države blagostanja, odnosno pozitivnog odnosa prema širenju opsega socijalne države i ostvarenja društvene pravednosti kao zadaće države, jasan je raskorak između izrazito pozitivnih stavova stranaka lijevo od centra (SPD, Zeleni, Ljevica) i stranaka desno od centra (CDU-CSU, FPD, Alternativa). Taj se raskorak u posljednjih nekoliko izbornih ciklusa značajno povećao, ponajprije zato što se Ljevica sukcesivno pomicala sve ljevije. Alternativa je isprva imala nešto pozitivnije stavove o državi blagostanja od liberala i Unije, no 2017. pomaknula se udesno i jasno se odmaknula od stavova obiju etabliranih političkih opcija desno od centra, čije se pozicije o tom pitanju na tim izborima preklapaju.

Uzevši u obzir sve tri ekonomske varijable, može se makar djelomice potvrditi da je Alternativa ekonomski doista desnija od ostalih parlamentarnih stranaka. Premda nije prema svim pokazateljima desnija od liberala, svakako se pozici- onira ekonomski desnije od CDU-a i CSU-a.

Prema varijabli koja mjeri pozitivne iskaze o osobnim slobodama i građanskim pravima, u cijelome promatranom razdoblju ističu se liberali, ali i Zeleni. Ostale stranke nisu davale nužno negativne iskaze o navedenim temama - ova varijabla to ne mjeri, a ne postoji druga varijabla u bazi podataka koja bi to detektirala - nego ne stavljaju naglasak na te teme, pa je zbog slabije pojavnosti respektivnih iskaza njihov rezultat niži. Alternativa se pozicionira uz bok Ljevici, a 2017. više od te stranke pozitivno tematizira osobne slobode i građanska prava, mnogo značajnije od SPD-a i stranaka Unije u cijelome promatranom razdoblju.

Rezultati prema varijabli koja mjeri pozitivne iskaze o demokraciji zanimljivi su zato što prema njima u gotovo cijelome promatranom razdoblju Zeleni i Ljevica prednjače u odnosu prema trima 
Grafikon 9. Njemačke parlamentarne stranke i stavovi o demokraciji, 1990-2017.

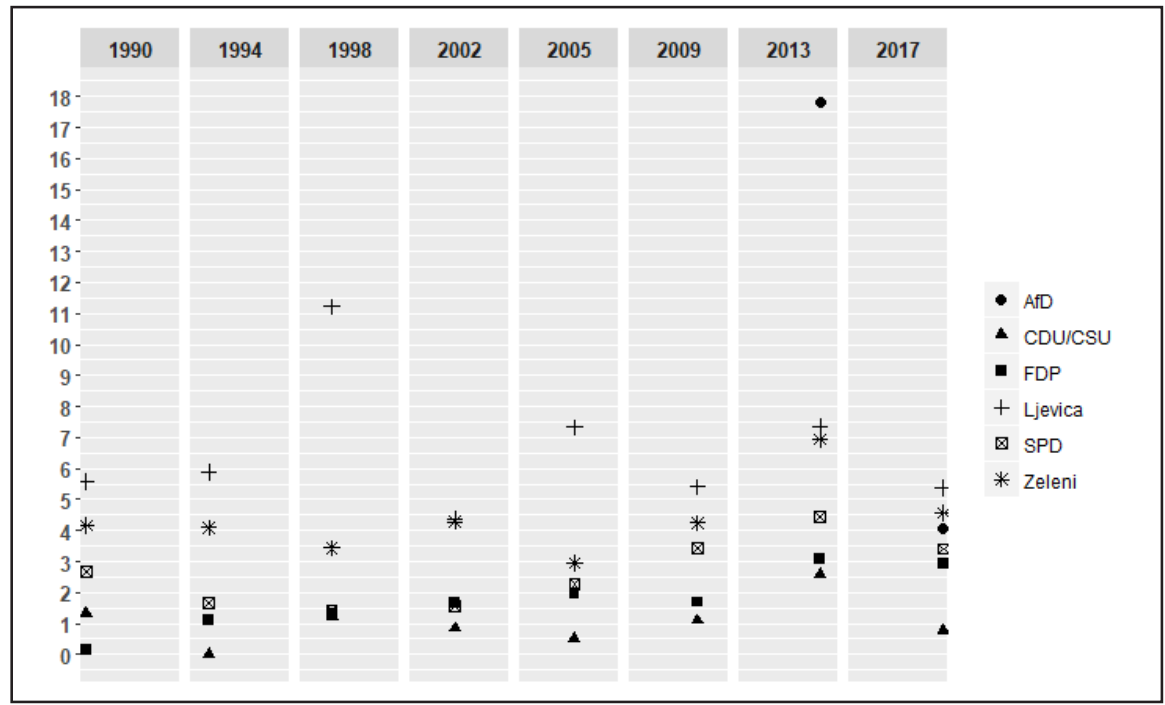

Izvor: izradio autor prema Volkens i dr. 2017b.

Napomena: veće vrijednosti predstavljaju više pozitivnih izjava o demokraciji u stranačkom programu.

starim etabliranim strankama, pri čemu je posebno odskakala Ljevica na izborima 1998. No poslije 2013. Alternativa zauzima poziciju koja intenzitetom svojih pozitivnih iskaza o demokraciji u stranačkom programu zasjenjuje sve ostale stranke, da bi se 2017. stavovi stranke "spustili" u mainstream ostavši još uvijek nešto ispred stranaka Unije, ali iza Zelenih i Ljevice.

Naposljetku, rezultati stranaka prema varijabli koja mjeri pozitivno određenje prema ustavnom poretku, zagovaranju ustavnih vrednota i očuvanju ustavnopravnog okvira pokazuju vrlo mala odstupanja u cijelom razdoblju. Ne može se govoriti da je neka stranka značajno promijenila svoju poziciju, ali se ne može ni potvrditi neki trend u cijelome stranačkom sustavu niti utvrditi da se neka stranka isticala svojim izrazito visokim ili niskim rezultatima na toj dimenziji. Stavovi Alternativa i 2013. i 2017. gotovo su identični stavovima stranaka Unije i vrlo su blizu stavovima ostalih stranaka. Drugim riječima, nijedna od promatranih stranaka u ci- jelome analiziranom razdoblja nije ni značajno više od drugih stranaka naglašavala očuvanje ustavnog poretka niti je zagovarala njegovu promjenu. Zanimljivo je da rezultati Alternative ne odstupaju značajnije od rezultata drugih stranaka, budući da se iz njezina programa za izbore 2017. može, među ostalim, iščitati kako se zauzima za izravan izbor saveznog predsjednika, ali bez povećavanja njegovih ovlasti (AfD 2017b: 9).

Uzmu li se u obzir sve tri promatrane varijable koje detektiraju stavove o liberalno-demokratskom poretku, nije moguće ustvrditi kako stavovi Alternative značajno odudaraju od stavova ostalih parlamentarnih stranaka. Budući da stavovi te stranke pokazuju nešto više vrijednosti od ostalih stranaka ili su posve jednake, ne može se na temelju tog segmenta izbornih programa govoriti o protudemokratskome ili protuustavnom karakteru Alternative. Odskakanje na dimenziji demokracije 2013, kada je Alternativa imala višestruko veći rezultat prema toj varijabli od svih ostalih stranaka, može se objasniti time što 
Grafikon 10. Njemačke parlamentarne stranke i stavovi o ustavnom poretku, 1990-2017.

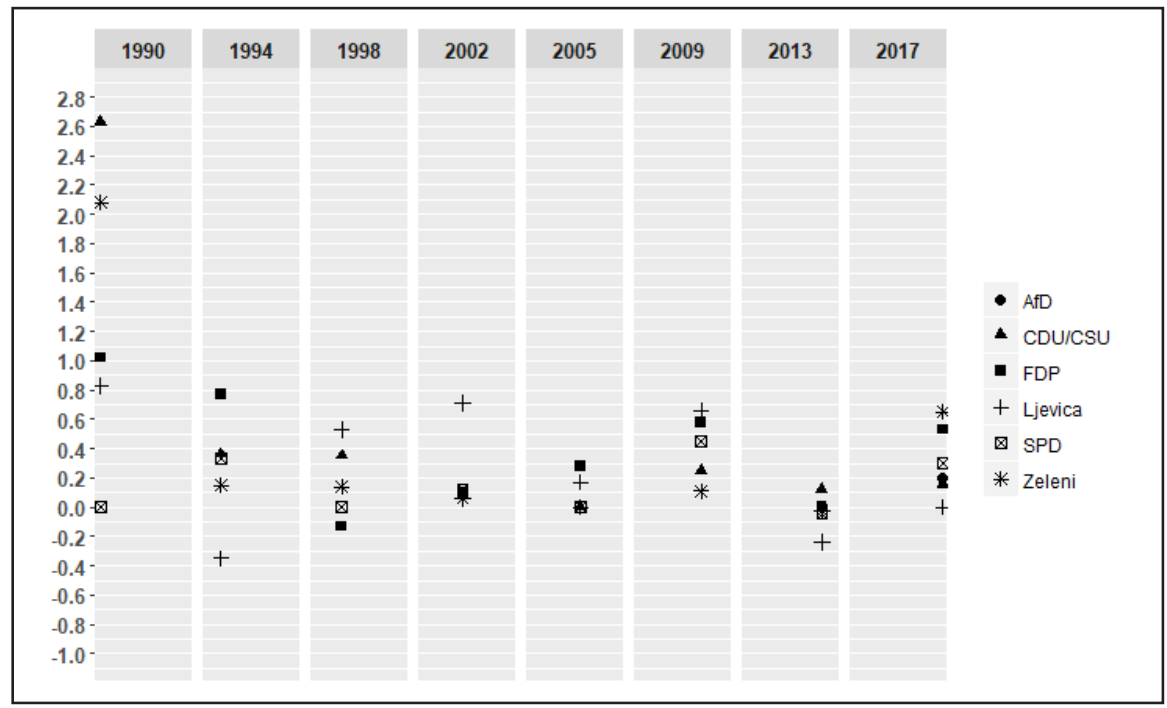

Izvor: izradio autor prema Volkens i dr. 2017b.

Napomena: veće vrijednosti predstavljaju više pozitivnih izjava o ustavnom poretku u stranačkom programu.

je programski inzistirala na uvođenju elemenata izravne demokracije prema uzoru na Švicarsku, kao i na uvođenju stranačkih predizbora američkog tipa, jačanju pokrajina naspram savezne vlasti te demokratiziranju izbora sudaca (AfD 2013: 12). Na temelju tih ekstremnih vrijednosti, a uzevši u obzir da indeks lijevo-desno (rile) sadržava i zasebno razmatrane demokratske varijable, može se objasniti naizgled začuđujući podatak da Alternativa prema drugim dimenzijama - stavovi o Europskoj uniji, nacionalnom načinu života, multikulturalizmu i ekonomskoj politici - bilježi značajno desnije stavove i od stranaka Unije i ostalih stranaka, a istodobno se na ljestvici lijevo-desno 2013. nalazila bliže centru od CDU-a, CSU-a i liberala.

U oblikovanju multivarijantnoga regresijskog modela prvo su uvršteni svi prediktori za koje se očekivalo da će pridonijeti objašnjenju promatranog ishoda (model 1. u tablici 2). Pritom je izračunat faktor inflacije varijance (VIF) kako bi se detektirala moguća kolinear- nost. ${ }^{10}$ Ona je doista utvrđena za varijable bivša DDR te ostali, oni koji se nisu izjasnili ili koji nemaju konfesionalnu pripadnost, s vrijednostima VIF-a koje uvelike premašuju 2,5. U sljedećem modelu (2) eliminirana je konfesionalna varijabla, čime je riješen problem kolinearnosti, neznatno je smanjen prilagođeni $\mathrm{R}^{2}$, a ponešto su poboljšani pokazatelji robustnosti samog modela (AIC, BIC). Kako bi se model dodatno "očistio", u konačnom modelu (3) izbačena je obrazovna varijabla (bez završsene niže srednje škole) koja nije bila statistički značajna u prethodna dva modela. Konačni model (3) pokazao je statistički značajnu regresijsku jednadžbu ( $\mathrm{F}(4$, 294) $=143,570 ; p<0,01)$, uz prilagođeni $\mathrm{R}^{2}$ od 0,657 . Drugim riječima, objašnjeno je gotovo dvije trećine varijance. Najvažniji pojedinačni prediktor u tom modelu jest varijabla bivša $D D R$ s B ko-

10 Postoje različiti pristupi određivanju graničnih vrijednosti iznad kojih je potrebno korigirati model kako bi se minimalizirala multikolinearnost, ali rasprava o tome nadilazi okvire ovog članka. 
Tablica 1. Socijalno-demografski čimbenici glasa za Alternativu (deskriptivna statistika)

\begin{tabular}{lrrrrrr}
\hline & $N$ & $M$ & SD & Min & C & Maks \\
\hline Drugi glasovi za AfD & 299 & 12,80 & 5,50 & 4,9 & 11,5 & 35,5 \\
Bivša DDR & 55 & & & & & \\
Ostali ili bez konfesionalne pripadnosti & 299 & 40,78 & 20,91 & 10,3 & 34,4 & 88,5 \\
Stanovništvo 75+ & 299 & 11,05 & 1,41 & 7,7 & 10,9 & 15,3 \\
\hline Nezaposleni & 299 & 6,13 & 2,42 & 2,0 & 6,0 & 14,1 \\
Nedržavljani & 299 & 10,11 & 5,40 & 1,2 & 9,4 & 31,4 \\
Bez završene niže srednje škole & 299 & 5,91 & 1,99 & 2,3 & 5,4 & 13,8 \\
\hline
\end{tabular}

Izvor: izradio autor prema BWL 2017a, 2017b.

Napomena: $M=$ aritmetička sredina, $S D=$ standardna devijacija, $C=$ srednja vrijednost.

eficijentom od 10,107 $(0,615)^{* * *}$. Isključivanje obrazovne varijable nimalo nije smanjilo postotak objašnjene varijance, ali je blago poboljšalo vrijednosti AIC-a i BIC-a, što naposljetku opravdava izbor trećeg modela $s$ četiri od početnih šest prediktora.

Regresijska analiza pokazala je, dakle, kako je najvažniji prediktor glasovanja za Alternativu regionalno obilježje okruga, to jest smještenost izbornog okruga na području bivše Istočne Njemačke, uz relativno nizak pozitivni koeficijent za dobnu strukturu okruga (udio starijeg stanovništva) i izrazito nizak pozitivni koeficijent za udio stranih državljana u okrugu. Takvi nalazi ne čude s obzirom na to da su i druge stranke desnije od CDU-a i CSU-a u prošlosti ponajbolje prolazile u okruzima bivše Istočne Njemačke, te da veći udio starijeg stanovništva, ako se pretpostavi da je prijemčivije za mobilizaciju strahova kakva je bila primjetna u izbornoj kampanji Alternative 2017, može biti dobar prediktor glasovanja za tu političku opciju. Zanimljivo je da udio stranih državljana neznatno pridonosi objašnjenju varijacije u glasovanju za stranku koja velik dio svoga političkog programa temelji na problematiziranju migracijske i integracijske politike. To se može objasniti time što ponajveći broj stranih državljana u Njemačkoj živi u velikima i srednje velikim industrijskim gradovima koji su još uvijek biračke utvrde socijaldemokrata. Nasuprot tome, prediktor koji se temelji na udjelu nezaposlenih u izbornom okrugu ima nizak, ali negativan koeficijent, što bi impliciralo da s blagim padom nezaposlenosti u nekom okrugu rastu izgledi glasovanja za Alternativu, što nije u skladu s očekivanjem da će upravo u okruzima s visokim udjelom nezaposlenih birači više glasovati za tu stranku.

Naposljetku se treba osvrnuti na tablicu 3. koja prikazuje rezultate analize biografskih obilježja vodstva Alternative. Uočljivo je da su muškarci značajno nadpredstavljeni - ugrubo, u omjeru 1 : 10. Premda je stranka najuspješnija na području bivše Istočne Njemačke, čelnici stranke iz tog dijela zemlje čine samo 18,8 posto vodstva, što je malo niže od udjela tog dijela zemlje u ukupnom stanovništvu Njemačke. Premda je opravdano pretpostaviti da su makar neki čelnici članovi jedne od dviju glavnih crkava u Njemačkoj - autoru ti podaci 
Tablica 2. Prediktori drugog glasa za Alternativu

\begin{tabular}{|c|c|c|c|c|c|c|}
\hline & \multicolumn{6}{|c|}{$\begin{array}{c}\text { Ovisna varijabla: } \\
\text { Drugi glasovi za AfD }\end{array}$} \\
\hline & \multicolumn{2}{|c|}{ Model 1} & \multicolumn{2}{|c|}{ Model 2} & \multicolumn{2}{|c|}{ Model 3} \\
\hline & & VIF & & VIF & & VIF \\
\hline Bivša DDR & $\begin{array}{l}11,926^{* * *} \\
(1,284)\end{array}$ & 7,153 & $\begin{array}{c}10,559^{* * *} \\
(0,717)\end{array}$ & 2,227 & $\begin{array}{c}10,107^{* * *} \\
(0,615)\end{array}$ & 1,634 \\
\hline $\begin{array}{l}\text { Ostali, neizjašnjeni } \\
\text { ili bez konfesionalne } \\
\text { pripadnosti }\end{array}$ & $\begin{array}{l}-0,029 \\
(0,023)\end{array}$ & 6,410 & & & & \\
\hline Stanovništvo $75+$ & $\begin{array}{l}1,243^{* * *} \\
(0,194)\end{array}$ & 2,147 & $\begin{array}{l}1,272^{* * *} \\
(0,193)\end{array}$ & 2,119 & $\begin{array}{l}1,290^{* * *} \\
(0,193)\end{array}$ & 2,107 \\
\hline Nezaposleni & $\begin{array}{l}-0,342^{* * *} \\
(0,111)\end{array}$ & 2,061 & $\begin{array}{l}-0,392^{* * *} \\
(0,104)\end{array}$ & 1,806 & $\begin{array}{l}-0,455^{* * *} \\
(0,090)\end{array}$ & 1,356 \\
\hline Nedržavljani & $\begin{array}{l}0,122^{* *} \\
(0,054)\end{array}$ & 2,447 & $\begin{array}{c}0,094^{*} \\
(0,049)\end{array}$ & 2,050 & $\begin{array}{c}0,095^{*} \\
(0,050)\end{array}$ & 2,048 \\
\hline $\begin{array}{l}\text { Bez završene niže } \\
\text { srednje škole }\end{array}$ & $\begin{array}{l}-0,155 \\
(0,144)\end{array}$ & 2,365 & $\begin{array}{l}-0,175 \\
(0,143)\end{array}$ & 2,338 & & \\
\hline Konstanta & $\begin{array}{l}-0,169 \\
(2,440)\end{array}$ & & $\begin{array}{l}-0,707 \\
(2,406)\end{array}$ & & $\begin{array}{l}-1,487 \\
(2,322)\end{array}$ & \\
\hline $\mathrm{N}$ & 299 & & 299 & & 299 & \\
\hline $\mathrm{R}^{2}$ & 0,665 & & 0,663 & & 0,661 & \\
\hline Prilagođeni $\mathrm{R}^{2}$ & 0,658 & & 0,657 & & 0,657 & \\
\hline Rez. st. pogreška & $\begin{array}{c}3,216 \\
(\mathrm{df}=292)\end{array}$ & & $\begin{array}{c}3,220 \\
(\mathrm{df}=293)\end{array}$ & & $\begin{array}{c}3,223 \\
(\mathrm{df}=294)\end{array}$ & \\
\hline F-statistika & $\begin{array}{c}96.607^{* * *} \\
(\mathrm{df}=6 ; 292)\end{array}$ & & $\begin{array}{c}115.345^{* * *} \\
(\mathrm{df}=5 ; 293)\end{array}$ & & $\begin{array}{c}143.570^{* * *} \\
(\mathrm{df}=4 ; 294)\end{array}$ & \\
\hline AIC & 1556,079 & & 1555,759 & & 1555,276 & \\
\hline $\mathrm{BIC}$ & 1585,682 & & 1581,662 & & 1577,478 & \\
\hline
\end{tabular}

a Prikazani su nestandardizirani koeficijenti, standardne pogreške u zagradama. $\mathrm{b}^{\star * *} \mathrm{p}<0,01{ }^{\star *} \mathrm{p}<0,05^{\star} \mathrm{p}<0,1$

nisu bili dostupni - udio deklariranih katolika i evangelika u vodstvu Alternative mnogo je niži od nacionalnog prosjeka, bez obzira na to što vodstvo uključuje i predstavnike kršćanskoga konzervativnog krila, poput Beatrix von Storch (Bebnowski, 2015: 25-27). Kakva je obrazovna struktura vodstva Alternative koja je nastala kao stranka profesora ekonomije? Više od 20 posto čine ekonomisti, 20 posto pravnici, a još je 25 posto završilo neki drugi fakultet. Dakle, nije riječ o stranci koja okuplja ljude s margine društva koji su zato postali "borci protiv sustava".

Posebno je zanimljiv podatak da je gotovo 47 posto članova vodstva Alternative $u$ prošlosti bilo u nekoj drugoj stranci. To znači da ona okuplja nezadovoljnike koji imaju iskustva u operativnoj politici, a ne politički demobilizirane i komunikacijski obespravljene građane. 
Tablica 3. Biografska obilježja vodstva Alternative

\begin{tabular}{|c|c|}
\hline$N$ & 32 \\
\hline & $\%$ \\
\hline Muškarci & 90,6 \\
\hline Žene & 9,4 \\
\hline Rođeni u DDR-u & 18,8 \\
\hline Rođeni izvan Njemačke & 3,1 \\
\hline Katolici & 12,5 \\
\hline Evangelici & 12,5 \\
\hline Druge konfesionalne zajednice & 3,1 \\
\hline Nepoznato ili bez konfesionalne pripadnosti & 71,9 \\
\hline Ekonomisti & 21,3 \\
\hline Pravnici & 21,3 \\
\hline Drugo fakultetsko obrazovanje & 25,0 \\
\hline Bez fakultetskog obrazovanja & 16,8 \\
\hline Nepoznato & 15,6 \\
\hline Prethodno stranačko članstvo & 46,9 \\
\hline $\mathrm{CDU} / \mathrm{CSU}$ & 25,0 \\
\hline SPD & 9,4 \\
\hline FDP & 6,3 \\
\hline Zeleni & 3,1 \\
\hline Druge stranke & 15,6 \\
\hline Vojna karijera & 9,4 \\
\hline Burschenschaft & 6,3 \\
\hline Heimatvertriebene & 12,5 \\
\hline
\end{tabular}

Izvor: izradio autor prema AfD, 2017a; AfD BB, 2017; AfD BE, 2017; AfD BW, 2017; AfD BY, 2017; AfD HE, 2017; AfD HH, 2017; AfD MV, 2017; AfD NI, 2017; AfD NRW, 2017; AfD RP, 2017; AfD SH, 2017; AfD SN, 2017; AfD SL, 2017; AfD ST, 2017; AfD TH, 2017; AfD Watch Bremen, 2017; Biermann i dr, 2017.

Četvrtinu vodstva čine bivši članovi CDU-a i CSU-a, što se poklapa s tezom o tome da je Alternativa nastala kao korektiv desno od centra, budući da je CDU pod Angelom Merkel otišao previše ulijevo. Jedan od najvećih promicatelja te teze upravo je predsjednik stranke i nekadašnji CDU-ov dužnosnik u Hessenu Alexander Gauland. U vodstvu ima i bivših socijaldemokrata i liberala, pa i Zelenih. Očekivanja da će u vodstvu biti bivši članovi stranaka s desnog ruba, kao što su Republikanci i NPD, potvr- đena su samo manjim dijelom: otkriveni su jedan bivši član Republikanaca i dvoje bivših članova Stranke ofenzive pravne države (Partei Rechtstaatlicher Offensive), poznatije kao Schill-Partei, nazvane prema vođi stranke, bivšemu hamburškom sucu Ronaldu Schillu. Nekoliko je članova vodstva promijenilo dva ili tri puta stranačku iskaznicu, što govori o tome da je riječ o osobama koje su se dugo "politički tražile". Zaključno, gotovo 10 posto vodstva stranke ima vojnu (časničku) karijeru, 6 posto bili su 
članovi studentskih bratstava iz tradicije Burschenschaften, a više od 12 posto potječe iz obitelji koje su prognane iz nekadašnjih istočnih krajeva Njemačke te iz neke srednjoeuropske ili istočnoeuropske zemlje.

Biografska analiza vodstva oslikava šarolik background stranke. Iz nje se može zaključiti da se uspon stranke djelomice može objasniti aktivnim buntom nezadovoljnika na desnom centru i desnici. No ne mogu se zaobići ni neka biografska obilježja koja se često nalaze u rubnima desnim sredinama u Njemačkoj, kao što su studentska bratstva (Burschenschaft) i zavičajne udruge prognanih iz nekadašnjih istočnih krajeva (Landsmannschaften). Biografski profil vodstva ne odgovara posve onome što se očekuje od desne populističke stranke, kao ni od stranke koja ističe tradicionalne kršćanske etičke i kulturne vrednote. Dakako, analizirani je uzorak bio prilično mali pa bi se cjelovitija slika o profilu stranačke elite Alternative dobila kada bi se $\mathrm{u}$ analizu uključio klub zastupnika u Bundestagu, a možda i zastupnici u pokrajinskima predstavničkim tijelima.

\section{Zaključak}

U članku sam analizirao politički profil Alternativa za Njemačku koja je u nekoliko godina izrasla u treću jakosnu stranku u Bundestagu. Njezin odnos prema ostalim strankama u njemačkome stranačkom sustavu analiziran je pomoću kodiranih izbornih programa. Rezultati pokazuju da Alternativa snažno odudara od ostalih stranaka zastupljenih u njemačkom parlamentu od ujedinjenja do 2017. svojim odnosom prema Europskoj uniji, nacionalnom ponosu i kulturi te multikulturalizmu kao integracijsko-kulturnom modelu, kao i da je ekonomski mnogo desnija od svih stranaka, osim FDP-a. Ti nalazi potvrđuju kako je doista riječ o euroskeptičnoj, etnonacionalističkoj stranci koja uvelike zastupa ekonomski liberalizam. Rezultati ispitivanja odnosa stranke prema osobnim slobodama i građanskim pravima, demokraciji i ustavnom poretku suprotni su očekivanjima da će ta stranka demonstrirati protudemokratske i protusustavske nazore. Dapače, zbog inzistiranja na izravnoj demokraciji, na mahove značajno odskače od drugih stranaka, a zahvaljujući takvim stavovima na ljestvici lijevo-desno (kompozitni RILE-indeks), ne zauzima krajnje desnu poziciju u odnosu prema drugima parlamentarnim strankama. Višestruka regresijska analiza pokazala je da su ključne varijable za predviđanje izbornog rezultata Alternative regionalno obilježje izbornog okruga, odnosno njegova smještenost na prostoru Istočne Njemačke, kao i visok udio starog stanovništva u okrugu. Suprotno očekivanjima, s padom udjela nezaposlenih, rastu izgledi da se glasuje za tu stranku, dok prisutnost stranih državljana $\mathrm{u}$ izbornom okrugu samo neznatno pridonosi objašnjenju glasovanja za Alternativu. Nadalje, analiza biografskih odrednica vodstva stranke otkrila je u njemu velik broj bivših članova stranaka Unije, ali i drugih političkih opcija. Česta je i vezanost stranačke elite za nacionalistička studentska bratstva i zavičajne udruge prognanika.

Kroz sve tri razine analize pokazalo se da su početna razmatranja o Alternativi kao catch-all prosvjednoj stranci desno od centra bila relativno utemeljena. Riječ je o stranci koja je vidno desnija od CDU-a i CSU-a, ali na temelju sagledanih podataka nije bilo moguće dokazati njezin ekstremistički, protudemokratski ili protusustavski karakter. Obilježja izbornih okruga u kojima stranka postiže najbolje rezultate svjedoče kako su posrijedi oni dijelovi Njemačke gdje prevladava stanovništvo koje se nalazi na margini društvenih i političkih zbivanja (istočni Nijemci, staro stanov- 
ništvo), koje gubitak osjećaja političke otuđenosti može lako naći u stranci koja nudi sadržaje onkraj standardne ponude javnih politika. Uz to, biografijska obilježja vodstva stranke svjedoče o tome da je riječ o okupljalištu osoba koje više nemaju svoj politički dom, a nekada su ga imali ponajprije u strankama Unije, ali i o stranci koja omogućava osobama s desnog ruba da uđu u politički mainstream.
Analiza na trima različitima razinama omogućuje bolje razumijevanje uloge i mjesta Alternative u njemačkome stranačkom sustavu te potiče nova istraživanja regionalnih razlika u njemačkome biračkom tijelu. No otvara i pitanja o budućnosti stranke na čiji ideološki profil nastoji utjecati vrlo raznovrsna skupina pojedinaca u rasponu od ekonomskih liberala preko društvenih konzervativaca do revizionističkih nacionalista. 


\section{Literatura}

AfD, Alternative für Deutschland, 2017a, Bundesvorstand. https://www.afd.de/ partei/bundesvorstand/ (pristupljeno 27. prosinca 2017).

AfD, Alternative für Deutschland, 2017b, Programm für Deutschland: Wahlprogramm der Alternative für Deutschland für die Wahl zum Deutschen Bundestag am 24. September 2017. https://www.afd.de/wp-content/uploads/ sites/111/2017/06/2017-06-01_AfDBundestagswahlprogramm_Onlinefassung.pdf (pristupljeno 27. prosinca 2017).

AfD, Alternative für Deutschland, 2013, Programm der AfD zur Bundestagswahl 2013. https://hughbronson.files. wordpress.com/2013/11/alternative fuer_deutschland1.pdf (pristupljeno 27. prosinca 2017).

AfD BB, Landesverband Brandenburg - Alternative für Deutschland, 2017, Der Vorstand der AfD-Brandenburg. http://www.afd-brandenburg.de/landesverband/vorstand/ (pristupljeno 27. prosinca 2017).

AfD BE, Alternative für Deutschland - Landesverband Berlin, 2017, Landesvorstand. http://afd.berlin/partei/ landesvorstand/ (pristupljeno 27. prosinca 2017).

AfD BW, Alternative für Deutschland - Baden-Württemberg, 2017, Landesvorstand. https://afd-bw.de/partei/ landesvorstand (pristupljeno 27. prosinca 2017).

AfD BY, Alternative für Deutschland - Landesverband Bayern, 2017, Der Landesvorstand Bayern. https://www. afdbayern.de/partei/landesvorstand/ (pristupljeno 27. prosinca 2017).

AfD HE, Alternative für Deutschland - Landesverband Hessen, 2017, Landesvorstand. https://www.afd-hessen. org/vorstand/ (pristupljeno 27. prosinca 2017).
AfD $\mathrm{HH}$, Alternative für Deutschland - Landesverband Hamburg, 2017, Landesvorstand. https://alternativehamburg.de/afd-hamburg-landesvorstand/ (pristupljeno 27. prosinca 2017).

AfD MV, Alternative für Deutschland - Landesverband Mecklenburg-Vorpommern, 2017, Der Landesvorstand. https://www.afd-mv.de/partei/ vorstand/ (pristupljeno 27. prosinca 2017).

AfD NI, AfD Niedersachsen, 2017, Der Vorstand der AfD Niedersachsen. http://afd-niedersachsen.de/partei/ organisation (pristupljeno 27. prosinca 2017).

AfD NRW, Alternative für Deutschland - Landesverband Nordrhein-Westfalen, 2017, Ihr Landesvorstand NRW. https://afd.nrw/partei/vorstand/ (pristupljeno 27. prosinca 2017).

AfD RP, AfD Rheinland-Pfalz, 2017, Vorstand. https://www.alternative-rlp. de/afd-in-rheinland-pfalz/vorstand (pristupljeno 27. prosinca 2017).

AfD SH, Alternative für Deutschland Landesverband Schleswig-Holstein, 2017, Der Landesvorstand der AfD Schleswig-Holstein. http://afd-sh.de/ index.php/landesverband/landesvorstand (pristupljeno 27. prosinca 2017).

AfD SN, AfD Freistaat Sachsen, 2017, Landesvorstand Sachsen. http://www. afdsachsen.de/landesverband/landesvorstand-sachsen.html (pristupljeno 27. prosinca 2017).

AfD SL, AfD Saar, 2017, Ihr Landesvorstand Saarland. https://afd.saarland/ partei/vorstand/ (pristupljeno 27. prosinca 2017).

AfD ST, AfD Sachsen-Anhalt, 2017, Ihr Landesvorstand Sachsen-Anhalt. https://afd-lsa.de/partei/vorstand/ (pristupljeno 27. prosinca 2017). 
AfD TH, Alternative für Deutschland - Landesverband Thüringen, 2017, Vorstand Landesverband Thüringen. http://afd-thueringen.de/vorstand/ (pristupljeno 27. prosinca 2017).

AfD Watch Bremen, 2017, Frank Magnitz | AfD Landesvorsitzender. https:// afdwatchbremen.com/frank-magnitz-landeschef-bremen/ (pristupljeno 27. prosinca 2017).

Bebnowski, David. 2015. Die Alternative für Deutschland: Aufstieg und gesellschaftliche Repräsentanz einer rechten populistischen Partei. Wiesbaden: Springer.

Berbuir, Nicole, Lewandowsky, Marcel, Siri, Jasmin. 2015. The AfD and its Sympathisers: Finally a Right-Wing Populist Movement in Germany? German Politics. (24) 2: 154-178.

Beyme, Klaus von. 2017. Das politische System der Bundesrepublik Deutschland: Eine Einführung. 12. izd. Wiesbaden: Springer.

Biermann, Kai i dr. 2017. AfD-Fraktion: Rechts bis extrem im Bundestag. Die Zeit. http://www.zeit.de/politik/deutschland/2017-09/afd-kandidaten-bundestagswahl-abgeordnete (pristupljeno 1. listopada 2017).

BWL, Der Bundeswahlleiter, 2017a. Strukturdaten für die Wahlkreise. https://www.bundeswahlleiter.de/bundestagswahlen/2017/strukturdaten. html (pristupljeno 25. listopada 2017).

BWL, Der Bundeswahlleiter, 2017b. Wahl zum 19. Deutschen Bundestag am 24. September 2017, Heft 3: Endgültige Ergebnisse nach Wahlkreisen. https:/www.bundeswahlleiter.de/dam/ jcr/3f3d42ab-faef-4553-bdf8-ac089b7de86a/btw17_heft3.pdf (pristupljeno 25. listopada 2017).

Debus, Marc. 2010. Soziale Konfliktlinien und Wahlverhalten: Eine Analyse der Determinanten der Wahlabsicht bei Bundestagswahlen von 1969 bis
2009. Kölner Zeitschrift für Soziologie und Sozialpsychologie. (62) 4: 731-749.

Decker, Frank. 2016. Die "Alternative für Deutschland" aus der vergleichenden Sicht der Parteienforschung. U: Häusler, Alexander. (ur.). Die Alternative für Deutschland: Programmatik, Entwicklung und politische Verortung. Wiesbaden: Springer, str. 7-24.

Elff, Martin, Roßteutscher, Sigrid. 2016. Parteiwahl und Nichtwahl: Zur Rolle sozialer Konfliktlinien. U: Schoen, Harald, Weßels, Bernhard. (ur.). Wahlen und Wähler: Analysen aus Anlass der Bundestagswahl 2013. Wiesbaden: Springer, str. 45-69.

Elff, Martin, Roßteutscher, Sigrid. 2011. Stability or Decline? Class, Religion and the Vote in Germany. German Politics. (20) 1: 107-127.

Focus.de 2017. Björn Höcke: Acht Zitate zeigen, wie gefährlich der AfD-Rechtsaußen wirklich ist. Focus. https:// www.focus.de/politik/deutschland/ bjoern-hoecke-sieben-zitate-zeigenwie-gefaehrlich-der-afd-rechtsaussenwirklich-ist_id_6536746.html (pristupljeno 25. listopada 2017).

Franzmann, Simon T. 2016. Calling the Ghost of Populism: The AfD's Strategic and Tactical Agendas until the EP Election 2014. German Politics. (25) 4: 457-479.

Gebhardt, Richard. 2013. Eine "Partei neuen Typs"? Die "Alternative für Deutschland" (AfD) vor den Bundestagswahlen. Forschungsjournal Soziale Bewegungen. (26) 3: 86-91.

Grabow, Karsten. 2016. PEGIDA and the Alternative für Deutschland: two sides of the same coin? European View. (15) 2: 173-181.

Grimm, Robert. 2015. The rise of the German Eurosceptic party Alternative für Deutschland, between ordoliberal critique and popular anxiety. International Political Science Review. (36) 3:264-278. 
Häusler, Alexander. 2016. Ausblick. U: Häusler, Alexander. (ur.). Die Alternative für Deutschland: Programmatik, Entwicklung und politische Verortung. Wiesbaden: Springer, str. 239-245.

Häusler, Alexander; Roeser, Rainer, Scholten, Lisa. 2016. Programmatik, Themensetzung und politische Praxis der Partei "Alternative für Deutschland" (AfD). Heinrich-Böll-Stiftung. E-Paper. http:// berlin.dgb.de/themen/ ++co++ad5b4e2a-a35c-11e6-b627-525400e5a74a (pristupljeno 20. studenoga 2017).

Inglehart, Ronald, Klingemann, HansDieter. 2010. Party Identification, Ideological Preference and the Left-Right Dimension among Western Mass Publics. U: Budge, Ian, Crewe, Ivor, Farlie, Dennis. (ur.). Party Identification and Beyond: Representations of Voting and Party Competition. Colchester: ECPR Press, str. 243-273.

Jankowski, Michael, Schneider, Sebastian, Tepe, Markus. 2017. Ideological alternative? Analyzing Alternative für Deutschland candidates' ideal points via black box scaling. Party Politics. (23) 6: 704-716.

Kasapović, Mirjana. 2014. Kombinirani izborni sustavi u Europi, 1945-2014. Parne komparacije Njemačke i Italije, Bugarske i Hrvatske. Zagreb: Plejada.

Lengfeld, Holger. 2017. Die "Alternative für Deutschland": eine Partei für Modernisierungsverlierer? Kölner Zeitschrift für Soziologie und Sozialpsychologie. (69) 2: 209-232.

Manow, Philip. 2016. Mixed Rules, Mixed Strategies: Parties and Candidates in Germany's Electoral System. Colchester: ECPR Press.

Niedermayer, Oskar. 2015a. Das deutsche Parteiensystem nach der Bundestagswahl 2013. U: Niedermayer, Oskar. (ur.). Die Parteien nach der Bundestagswahl 2013. Wiesbaden: Springer, str. 1-23.
Niedermayer, Oskar. 2015b. Eine neue Konkurrentin im Parteiensystem? Die Alternative für Deutschland. U: Niedermayer, Oskar. (ur.). Die Parteien nach der Bundestagswahl 2013. Wiesbaden: Springer, str. 175-207.

Rohrschneider, Robert, Whitefield, Stephen. 2017. Party Positions about European Integration in Germany: An Electoral Quandary? German Politics. (26) 1: 83-103.

Schoen, Harald, Weßels, Bernhard. 2016. Die Bundestagswahl 2013 eine Zäsur im Wahlverhalten und Parteiensystem? U: Schoen, Harald, Weßels, Bernhard. (ur.). Wahlen und Wähler: Analysen aus Anlass der Bundestagswahl 2013. Wiesbaden: Springer, str. 3-20.

Schmitt-Beck, Rüdiger. 2017. The "Alternative für Deutschland in the Electorate": Between Single-Issue and Right-Wing Populist Party. German Politics. (26) 1: 124-148.

Schwarzbözl, Tobias, Fatke, Matthias. 2016. Außer Protesten nichts gewesen? Das politische Potenzial der AfD. Politische Vierteljahresschrift. (57) 29: 276-299.

Spiegel.de 2010. Integration: Merkel erklärt Multikulti für gescheitert. Spiegel Online. http://www.spiegel.de/ politik/deutschland/integration-merkel-erklaert-multikulti-fuer-gescheitert-a-723532.html (pristupljeno 25. listopada 2017).

Volkens, Andrea i dr. 2017a. The Manifesto Project Dataset - Codebook. Manifesto Project (MRG/CMP/MARPOR). verzija 2017b. Berlin: Wissenschaftszentrum Berlin für Sozialforschung (WZB).

Volkens, Andrea i dr. 2017b. The Manifesto Data Collection. Manifesto Project (MRG/CMP/MARPOR). verzija 2017b. Berlin: Wissenschaftszentrum Berlin für Sozialforschung (WZB). https://doi.org/10.25522/manifesto. mpds.2017b 


\title{
Alternative for Germany: Program, Leadership and Voters
}

\begin{abstract}
This paper analyzes the political profile of the Alternative for Germany to contribute to the understanding of its emergence in the German political life. An analysis of electoral manifestos tests the party's left-right position, stances on European integration, nationalism, and multiculturalism as well as on economic policy and democracy. A multiple regression analysis examines the predictive power of religion, age, education, migration, and economic status as characteristics of electoral districts explaining the variation in the party's vote percentage. An assessment of biographies of the party's leadership tests the presumed common demographic and ideologic background of the party elite. The article shows that new party differs from other German parties regarding the EU, nationalism, and multiculturalism, and economic policy, yet does not represent an outlier on the left-right scale, nor in its stance on democracy. The study of predictors of the vote for the Alternative for Germany has shown that regional (East/West cleavage), age and economic characteristics of electoral districts hold most importance. The biographic analysis of the party elite reveals a high percentage of previous CDU/CSU members and a dominance of elderly, well-educated men.
\end{abstract}

Key words Alternative for Germany, new party, German party system, social cleavages, euroscepticism 